\title{
3 Processing trade, trade liberalisation, and opening up: China's miracle of international trade
}

\author{
Yu Miaojie and Zhu Huihuang
}

\section{Introduction}

China began to reform its economy in 1978, and that economy has continued to grow rapidly over the past four decades. That such a large economy can achieve such long-term sustainable development has been seen as a miracle. One obvious feature of this miracle is that China has participated deeply and extensively in the global international trading system. Due to its opening-up policies, China has become the largest trading country in the world. In 2018, its foreign trade was valued at $\$ 4.62$ trillion, with exports of $\$ 2.48$ trillion and imports of $\$ 2.14$ trillion. China replaced Germany as the largest exporter in the world in 2009, and the United States (US) as the largest importer in 2015. Over the past four decades, China's foreign trade volume has increased 204-fold, whereas its gross domestic product has only increased 34 -fold. In this regard, China has already successfully achieved a miracle of foreign trade. Thus, to understand the miracle of China's economic growth, it is necessary to understand what role international trade has played in this process.

The realisation of this foreign trade miracle can be broken into four steps: the extensive margin of opening up (before 2001), the intensive margin of opening up (2001-08), deeper opening up against financial crises (2008-17), and allaround opening up (since 2017) after China's Communist Party announced the establishment of a new era of all-around opening up in China in its 19th National Congress.

The first stage was the extensive margin of opening up. During this period, the main feature of China's international trade was the utilisation of the country's huge labour force, which provides China with comparative advantages in labour-intensive industries and processing trade. Along with the decline of trade barriers between countries all over the world, the development of transportation and communication technologies, and the separation of production processes, China began integrating into the global value chain and taking advantage of its abundant labour force. A typical example of this integration was China's preferential trade policy of importing intermediate goods with zero tariffs to encourage processing trade production. Firms who participated in processing trade specialised in tasks requiring labour-intensive 
production. At the same time, by participating in processing trade and importing intermediate goods and capital goods, Chinese firms gradually became familiar with production technology and gained experience from foreign companies, which further improved their production and operation efficiency.

The second stage was the intensive margin of opening up. The main feature of this period was trade liberalisation in China and dramatic changes in Chinese firms' performance, product market, and intermediate market. On the one hand, opening up brought intensive import competition, compelling domestic firms and companies to reduce inefficiency and improve product quality to become more competitive. On the other hand, the reduction of import tariffs allowed domestic companies to purchase highquality intermediate goods and capital goods, allowing them to save costs and upgrade technology. At the same time, export trade liberalisation (for example, the removal of the Multi-Fiber Arrangement) expanded Chinese firms' foreign markets. These market-scale effects can stimulate enterprises to increase investment, research and development (R\&D), innovation, and export. Furthermore, along with the increased labour costs, the proportion of processing trade (a relatively low value-added trade mode) gradually decreased, and ordinary trade began to dominate.

The third stage was deeper opening up against the financial crisis. The global financial crisis in 2008 had significant negative impacts on the economic development of the global economy, especially in developed economies. Demand from major developed economies was weak, and the mode of relying mainly on exports to drive China's economic growth was no longer feasible. Thus, Chinese firms began to find new advantages, including quality, brand, service, and so on. On the other hand, the Government of China also implemented several actions to encourage local firms to improve product quality, provide first-class service to their customers, and, at the same time, attract multinational companies to invest in China.

The fourth stage is the all-around opening up. In 2017, the 19th National Congress of the Communist Party of China pointed out that China's economy has shifted from a high-speed increase stage to a high-quality development stage, and improving the supply quality has become a top priority. At the same time, trade protectionism and anti-globalisation forces are on the rise. Against this background, the government proposes to build a new pattern featuring all-around opening up, thus promoting the development of both the Chinese and global economies. Specific measures to be undertaken include (i) further widening market access, (ii) improving the investment environment for foreign investors, (iii) strengthening protection of intellectual property rights, and (iv) taking the initiative to expand imports. In doing so, China will send a message to the world that China's door will not be closed and will only open even wider. 


\section{Comparative-advantage-following and processing trade}

Before opening up its policy, China adopted a heavy industry-oriented development strategy - a comparative-advantage-defying development strategy. Lin and $\mathrm{Yu}(2015)$ found that a development strategy that prioritised heavy industry (which is a comparative-advantage-defying strategy) distorted product and factor prices, and had to rely on a highly centralised planned resource allocation mechanism. Thus, before the reform China adopted a distorted macroeconomic policy, which included suppressing interest rates, over-valuing domestic currency, adopting an import-substitution strategy, setting up 'price-scissors' against peasants, and restricting labour migration. After the 1978 economic reform, China abandoned the heavy industry-oriented development strategy, adopting the comparative-advantage-following (CAF) development strategy based on its factor endowments.

Where does China's comparative advantage lie? Yao and Yu (2009) found that a low dependent rate ${ }^{1}$ and low urbanisation rate contribute significantly to China's large labour force and low wages. This provides China with a long-term advantage in labour-intensive industries. Tian et al. (2013) used cross-country data and a gravity model to show that a large labour population has a positive effect on a country's imports and exports. Ma, Tang, and Zhang (2014) found that firms become less capital-intensive but more productive after exporting, compared to non-exporters with similar ex-ante characteristics.

After its economic reform, China adopted a CAF development strategy. The government realised that processing trade is an ideal way to implement the CAF strategy given that China is a labour-abundant country. Indeed, processing trade is one of the main causes of the high level of intra-industry trade among the capital-intensive industries mentioned above (Lin and $\mathrm{Yu}$, 2015). The General Administration of Customs reports 16 specific types of processing trade in China. Of these, the two most important are processing with assembly and processing with inputs. Both types of processing trade are duty-free but they are characterised by an important difference. For processing with assembly, a domestic Chinese firm obtains raw materials and parts from its foreign trading partners without any payment. However, after local processing, the firm must sell its products to the same foreign trading partner by charging an assembly fee. By contrast, for processing with inputs, a domestic Chinese firm pays for raw materials from a foreign seller. After local processing, the Chinese firm can then sell its final goods to other foreign countries ( $\mathrm{Yu}, 2015)$.

Compared with ordinary imports, processing imports in China accounted for just a small proportion of total imports in the early 1980s. However, as shown in Figure 3.1, China's processing imports increased dramatically in the early 1990s and began to dominate ordinary imports in 1992, when China officially announced the adoption of a market economy. In 1995, processing imports accounted for more than $50 \%$ of the country's total imports (now decreased to 


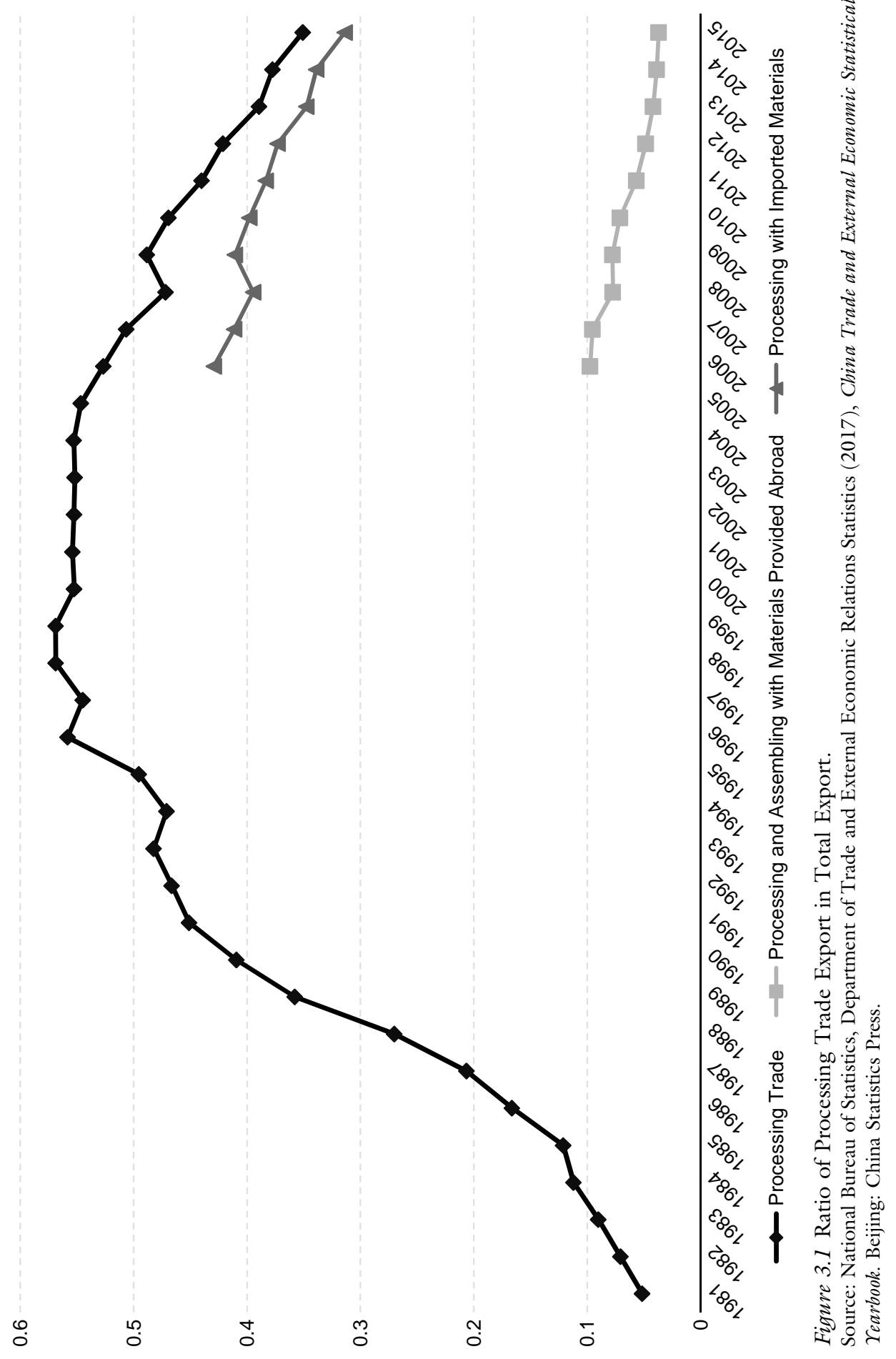


one-third of total trade). Interestingly, processing imports with assembly were more popular in the 1980s because most Chinese firms lacked the capital needed to import. Since the 1990s, processing imports with inputs have become more prevalent.

Due to the prevalence of processing trade, the literature has revisited some international trade theory, one of the main findings of which is the paradox of Chinese exporters' productivity. The firm-level trade literature finds that exporters are exceptional performers for a wide range of countries and measures (Melitz, 2003). Paradoxically, the one documented exception is the world's largest exporter, China. Dai, Maitra, and Yu (2016) showed that this puzzling finding is entirely driven by firms that engage only in export processing - the activity of assembling tariff-exempted imported inputs into final goods for resale in foreign markets. They document that processing exporters are less productive than non-processing exporters and non-exporters, and perform more poorly in many other aspects such as profitability, wages, R\&D, and skill intensity. Furthermore, accounting for processing exporters explains the abnormality in exporter performance in China documented in the previous literature. Although processing trade accounts for half of China's exports, processing firm productivity is lower than that of non-processing (i.e. ordinary) firms and even lower than that of non-exporters. Once they drop processing firms, Chinese exporters are more productive than non-exporters, meaning that the paradox disappears. Low fixed costs of processing exporting and trade and industrial policies favouring processing exporters are both responsible for the low productivity of processing exporters. Tian and $\mathrm{Yu}(2015)$ found rich evidence that a reduction in input trade costs for large trading firms leads to an increase in export intensity (i.e. exports over total sales). This impact is more pronounced for ordinary firms than for hybrid firms that engage in both processing and ordinary trade since ordinary imports enjoy duty-free treatment in China. Declining input trade costs not only increase the probability of a firm's being a new exporter (i.e. extensive margin) but also lead to higher export intensity (i.e. intensive margin).

Another main finding is how input and output tariffs affect a firm's productivity. Yu (2015) showed that reducing output tariffs has had a greater effect on productivity improvement than has reducing input tariffs for large Chinese trading firms in the 21 st century. Such results are primarily attributable to the special tariff treatment afforded to imported inputs by processing firms as opposed to non-processing firms in China. Processing imports, which account for half of the total imports in China, have zero tariffs. He documents that further tariff reductions on imported intermediate inputs have no impact on firms that engage entirely in processing trade but still have some impact on firms that engage in both processing and non-processing trade. As the firm's processing share grows, input tariff reductions have a smaller impact on productivity gains. Similarly, as a firm's processing share increases, the share of domestic sales decreases accordingly; and the pro-competition effects from the reductions in output tariffs are hence weaker. 


\section{Miaojie $Y u$ and Huibuang Zhu}

\section{Trade liberalisation and firm performance}

China's accession to the World Trade Organization (WTO) has had a profound influence on the world economy. However, this step took China far longer than it did other economies. As one of the 23 contracting parties to the General Agreement on Tariffs and Trade (GATT), it took China 15 years, from 1986 to 2001, to accede to the WTO. Wong and Yu (2015) observe this interesting phenomenon and argue that the level of democracy of an applicant country affects the time it takes to gain GATT/ WTO accession. They find that most GATT/WTO members are democratic. More interestingly, democratic regimes seem to take less time to accede to the GATT/ WTO than do non-democratic regimes. For example, Hong Kong acceded to GATT in 1986 immediately after its application. In contrast, Congo took more than 26 years to accede to the WTO. In addition, democratising countries also suffer from the length of time spent in attempting to accede to this large global trading organisation.

Democracy also has an impact on economic performance and export. Giavazzi and Tabellini (2005) provided evidence that countries that liberalise and then democratise perform much better than countries that do the reverse. Eichengreen and Leblang (2008) argued the existence of two-way positive causality between trade openness and democracy using historical data from 1870 to 2000. Yu (2010a) documents that democracy affects trade through different channels. First, democratisation in the exporting country can improve product quality and reduce trade costs, increasing bilateral trade. Second, democratisation in the importing country may increase trade barriers and thus reduce imports.

After China's accession to the WTO, along with the significant reduction in applied tariff rate (Figure 3.2), China's exports, firm performance, industrial structure, and factor market have undergone huge developments. According to the empirical findings of other countries, import trade liberalisation mainly affects firms in one country through two following channels: one is the intense competition caused by trade liberalisation in the final goods market; the other is the effect of tariff reductions on imported intermediate inputs (Amiti and Konings, 2007; Goldberg et al., 2010; Topalova and Khandelwal, 2011). On the one hand, import trade liberalisation and tariff reductions make it easier for foreign companies and their products to enter the domestic market, leading to greater competition for domestic companies and products. This will force domestic firms to reduce inefficiency in operations, markup and product price to better cope with the competition. On the other hand, tariff cuts have enabled many companies to purchase better quality intermediates at lower prices, which permits cost savings and quality upgrades.

Amiti and Konings (2007) analysed Indonesian firm-level data and find that firms gain at least twice as much from the reduction of input tariffs as from the reduction of output tariffs. Furthermore, Topalova and Khandelwal (2011) found that Indian firms could gain 10 times as much from input tariff reduction as from output tariff reduction in several industries. They argue forcefully that the primary reason for this result is that access to better intermediate inputs through the reduction of input tariffs is more important than the procompetitive effect of the reduction of output tariffs. 
In addition to the commonality with the trade liberalisation process in other developing countries, many studies use Chinese firm-level data to study how trade liberalisation affects firm productivity. Firstly, trade liberalisation can boost firm productivity through different channels. Yu, Ye, and Qu (2013) investigated the linkage between firm productivity and product complexity. First, they adopt the Olley-Pakes (1996) approach to address two empirical challenges: simultaneity bias and selection bias caused by ordinary least squares. Then, the estimation results suggest that trade liberalisation significantly increases productivity for firms that produce complex goods. In contrast, they find that trade liberalisation has the opposite effect on the productivity of producers of simple goods.

Secondly, trade liberalisation can boost firm total factor productivity through R\&D and innovation. Dai and Yu (2013) argue that absorptive capacity developed through pre-export R\&D investment is crucial for learning to occur. They estimate the instantaneous and long-term productivity effects of starting to export on the universe of Chinese manufacturing firms during 2001-07 using propensity score-matching techniques. The baseline results show that, while the productivity effect of exporting is weak and transient for all firms on average, it is large and lasting for firms with pre-export R\&D. For firms without pre-export R\&D, exporting has no significant productivity effect, even instantaneously. In

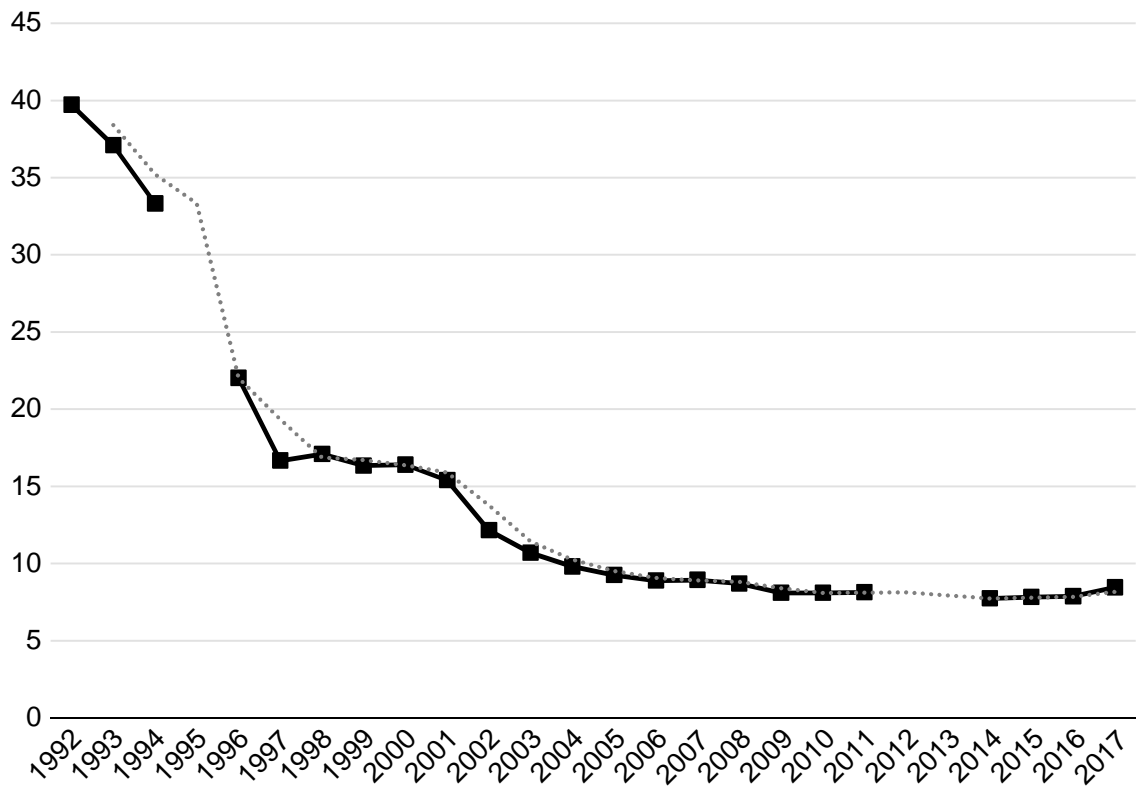

Figure 3.2 Applied Tariff Rate, Simple Mean, All Products (\%).

Source: The World Bank, World Bank Open Data, retrieved 15 November 2019 from: https:// data.worldbank.org/indicator/TM.TAX.MRCH.SM.AR.ZS 
addition, the productivity effect of exporting increases with the number of years of pre-export R\&D investment, suggesting that firms involved in intentional and persistent R\&D activities enjoy greater learning effects than do firms only accidentally involved in R\&D activities. They suggest that policies that encourage firm R\&D and other absorptive capacity-building activities should be combined with trade liberalisation to reap the full growth benefits of openness. Tian and $\mathrm{Yu}$ (2017) also find strong evidence that input trade liberalisation due to the WTO accession significantly fosters firm R\&D activity.

Furthermore, trade liberalisation can boost firm total factor productivity by increasing import variety. Feenstra, $\mathrm{Li}$, and $\mathrm{Yu}$ (2014) use Chinese firm-level data to confirm the positive effect of imported intermediate goods on firm productivity. The results are primarily attributable to spillover and competition effects from imported goods. However, they find that the impact of imported intermediate inputs on firm productivity becomes weaker as firms produce more complex products. Differentiated products, which account for four-fifths of total products, to some extent bear less pressure from severe competition but enjoy fewer benefits from foreign imports penetrating the domestic market than do homogeneous products. However, the growth in productivity of firms that produce heterogeneous goods is slower than that of firms that produce homogeneous goods when product complexity requires more imported intermediate goods. If a homogeneous intermediate input is imported, firms will find it easier to adopt its up-to-date technology because homogeneous products are less technology-specific than heterogeneous products.

Finally, Yu and Yuan (2016) have also found that the reduction of final tariffs has led to a decline in firms' production cost, and the reduction of tariffs on intermediate goods has led to an increase in firms' production cost. As a firm's processing share increases, the impact of the reduction in tariffs on firms' markup will be smaller. Yu and $\mathrm{Li}$ (2016) investigate the impact of trade liberalisation on the quality of imported inputs within narrow product categories. They follow the model in Khandelwal (2010) to estimate the quality of inputs imported to China. To estimate the impact of both input tariff reductions and output tariff reductions, they choose processing trade, which is free from both tariffs, as a control group. By implementing the difference-in-difference method, they find evidence to support the argument that trade liberalisation promotes the quality of imported inputs in ordinary trade relative to processing trade. Yu and Jin (2015) study the impact of imported intermediate inputs and imports of final goods on the firm by taking product complexity into account. After controlling for the endogeneity of imported intermediate inputs, they confirm that firms could benefit from imports. Further, they find that imports could improve the productivity of firms that produce homogeneous goods, but have little effect on those produce complex goods. To explain this heterogeneous effect, market concentration is introduced, and the result reveals that the import competition effect weighs more in homogeneous industry while the import spillover effect is more important to heterogeneous industry. The low impact of imports on firm productivity in heterogeneous industry could be explained by a weak import 
spillover effect due to low R\&D efficiency. Yu and Zhi (2016) find that, in the short term, import liberalisation of final goods allows more foreign firms to export to the domestic market, intensifying domestic market competition and thus reducing the profitability of pure domestic selling firms. However, in the long term, since firms can choose whether to enter or exit the market, some domestic reigning firms will choose to exit, allowing the firms that remain in the market to enjoy higher profitability in equilibrium.

Trade liberalisation also affects within-firm income inequality. Chen, Yu, and Yu (2017) develop a Mincer (1974)-type approach to investigate the impact of input trade liberalisation on firms' wage inequality between skilled and unskilled workers (or skill premium). When controlling for product-market tariffs in a firm's industry, they find robust evidence that reduced input tariffs in a firm's industry are associated with a higher skill premium at firms with more skilled workforces. This effect is more pronounced at ordinary (non-processing) firms. They also provide evidence that reduced input tariffs in a firm's industry are associated with higher value added and profits at firms with more skilled workforces. Rodriguez-Lopez and Yu (2017) also find a link between trade liberalisation and firm employment. They document a phenomenon where reductions in Chinese and foreign final-good tariffs are associated with job destruction in low-productivity firms and job creation in high-productivity firms. In contrast, the net effect of reductions in Chinese input tariffs is limited to job destruction in low-productivity ordinary exporters.

Moreover, Loren et al. (2017) observe the effects of the trade liberalisation that accompanied China's WTO accession on the evolution of markups and productivity of Chinese manufacturing firms. They show that cuts in output tariffs reduce markups but raise productivity, while cuts in input tariffs raise both markups and productivity. They highlight several mechanisms operating in liberalised sectors that help explain our findings in the Chinese context. Liberalised sectors saw an increase in the exit of private firms and more frequent replacement of management in badly performing state-owned firms. Lim, Trefler, and Yu (2019) use both econometrics and a calibrated structural model to disentangle the mechanisms via which trade affects innovation, focusing on scale effects (impact on market size) and competition effects (impact on markups). They find that both scale and competition effects are important for understanding how trade affects innovation in China. In particular, scale effects of trade on innovation are positive in the aggregate, whereas competition effects are negative. However, when firms can innovate to escape competition, greater competition induced by lower trade barriers can lead firms to increase innovation rather than reduce it.

In addition to trade liberalisation and reductions in import tariffs, Chinese firms also experienced export trade liberalisation, which has greatly expanded the international market faced by Chinese firms. Khandelwal, Schott, and Wei (2013) examine Chinese textile and clothing exports before and after the elimination of externally imposed export quotas. Both the surge in export volume and the decline in export prices following quota removal are driven by net entry. 
This outcome is inconsistent with a model in which quotas are allocated based on firm productivity, implying the misallocation of resources. Removing this misallocation accounts for a substantial share of the overall gain in productivity associated with quota removal. Feng, Li, and Swenson (2017) study how a reduction in trade policy uncertainty affects firm export decisions. Using a firmproduct level dataset on Chinese exports to the US and the European Union in the years surrounding China's WTO accession, they provide strong evidence that the reduction in trade policy uncertainty simultaneously induced firm entries to and exits from export activity within fine product-level markets. In addition, they uncover accompanying changes in export product prices and quality that coincided with this reallocation: firms that provided higher quality products at lower prices entered the export market, while firms that provided lower quality products at higher prices prior to the changes exited. To explain the simultaneous export entries and exits, as well as the fact that new entrants are more productive than exiters, they provide a model of heterogeneous firms that incorporates trade policy uncertainty, tracing the effects of the changes in policy uncertainty on firm-level payoffs and the resulting selection effects.

Despite the substantial reduction in tariff rates, recent literature notices a new aspect - non-tariff measures (NTMs) - that is gaining more importance than ever before, sometimes hampering the flow of international trade. NTMs are defined as 'policy measures, other than ordinary customs tariffs, that can potentially have an economic effect on international trade in goods, changing quality traded, or prices or both' (United Nations Conference on Trade and Development [UNCTAD], 2013). Ing, Li, and $\mathrm{Yu}$ (2019) have identified and collected all currently enforced NTMs in China, and provide a brief overview of the diverse types of NTMs that exist in China based on national laws and regulations.

\section{Deeper opening up against financial crisis}

The global financial crisis has had far-reaching repercussions on cross-border economic activity. After a sharp and sudden collapse in international trade in the last quarter of 2008, world trade flows declined by about $12 \%$ in 2009 according to the WTO (Chor and Manova, 2012). This exceeded the estimated loss of $5.4 \%$ of world gross domestic product during the same period. The contraction in exports was especially acute for small open economies, several of whom saw their trade volumes in the second half of 2008 fall by up to $30 \%$ year-on-year.

This trade decline contributed to the spread of recessionary pressures to countries which had little direct exposure to the US subprime mortgage market where the crisis originated. By exploiting the variation in the cost of capital across countries and over time, as well as the variation in financial vulnerability across sectors, Chor and Manova (2012) show that credit conditions were an important channel through which the crisis affected trade volumes. They notice that countries with higher interbank rates and thus tighter credit markets exported less to the US at the peak of the crisis. This effect was especially pronounced in sectors that require extensive external financing, have limited access to trade 
credit, or have few collateralisable assets. Exports of financially vulnerable industries were thus more sensitive to the cost of external capital than exports of less vulnerable industries, and this sensitivity rose during the financial crisis.

In the context of China, credit constraints faced by exporters played a significant role in the fall in exports. Manova, Wei, and Zhang (2015) use China's customs data to provide firm-level evidence that credit constraints restrict international trade and affect the pattern of multinational activity. They show that foreign affiliates and joint ventures in China have better export performance than private domestic firms in sectors that are more financially vulnerable. These results are stronger for destinations with higher trade costs, and are not driven by firm size or other sector characteristics. These findings are consistent with multinational subsidiaries being less constrained by liquidity because they can access foreign capital markets or funding from their parent company.

Feenstra, Li, and Yu (2014) examine why credit constraints for domestic and exporting firms arise in a setting where banks do not observe firms' productivities. To maintain incentive compatibility, banks lend below the amount that firms need for optimal production. The longer time needed for export shipments induces a tighter credit constraint on exporters than on purely domestic firms. Using Chinese firm-level data, they find that the credit constraint becomes more stringent as a firm's export share grows, as the time to ship for exports is lengthened, and as there is greater dispersion of firms' productivities, reflecting more incomplete information.

Accompanied by the export pressure caused by the global financial crisis, the increase in China's labour cost and appreciation of the renminbi also eroded China's export competitiveness significantly, especially in labour-intensive industries. We focus on three main solutions to expand trade volume. The first of these is to increase the firm's R\&D. Dai, Yu, and Zhao (2018) find that competition plays an important role in providing incentives for firm innovation. They use the appreciation of the renminbi exchange rate during 2005-07 as a natural experiment and exploit its differential impact on Chinese manufacturing firms with different export exposures. The appreciation reduced exports and imposed greater competitive pressure on exporters relative to non-exporters. In response, exporters increased innovation activities more than did non-exporters. Using a difference-in-difference approach, they find that the R\&D expenditure of exporters increased by $11 \%$ more than that of non-exporters during the appreciation period, and the new product development of exporters increased by nearly 1.5 times more than that of non-exporters.

The second solution is to upgrade the quality of exported goods. First, it is necessary to examine how Chinese manufacturers' export quality has evolved since 2000. Yu and Zhang (2017) developed a new method to estimate export quality and avoid pitfalls in the literature. Using China's manufacturing firm data and customs data from 2000 to 2006, they estimate firm-product-destinationyear level export quality and find that the overall export quality of Chinese manufacturers has increased by $15 \%$. The quality gap between foreign and domestic firms has narrowed, with domestic firms exhibiting quality convergence. 
Table 3.1 Quality Distribution, China 2000-13

\begin{tabular}{ccccc}
\hline Year & Mean & Median & 75th Percentile & 25th Percentile \\
\hline 2000 & 1.217 & 1.072 & 1.677 & 0.550 \\
2001 & 1.242 & 1.111 & 1.714 & 0.579 \\
2002 & 1.242 & 1.105 & 1.704 & 0.588 \\
2003 & 1.247 & 1.111 & 1.724 & 0.587 \\
2004 & 1.293 & 1.151 & 1.772 & 0.621 \\
2005 & 1.335 & 1.191 & 1.817 & 0.664 \\
2006 & 1.383 & 1.232 & 1.882 & 0.684 \\
2007 & 1.371 & 1.210 & 1.881 & 0.650 \\
2008 & 1.444 & 1.267 & 1.968 & 0.689 \\
2009 & 1.449 & 1.275 & 2.007 & 0.666 \\
2010 & 1.470 & 1.297 & 2.038 & 0.689 \\
2011 & 1.493 & 1.303 & 2.063 & 0.684 \\
2012 & 1.558 & 1.351 & 2.184 & 0.687 \\
2013 & 1.588 & 1.360 & 2.218 & 0.702 \\
\hline
\end{tabular}

Source: Ing, Yu, and Zhang (2018).

Export quality increases for most industries are higher in high-income destinations and are negatively associated with both export and import tariffs. Surviving varieties contribute to most of the aggregate export quality upgrading, while low-quality existing varieties facilitate the aggregate export quality upgrading. Ing, Yu, and Zhang (2018) estimated micro-level firm-product-destination-year export quality for China (2000-13).

As shown in Table 3.1, from 2000 to 2013, the quality of Chinese exports increased by $30 \%$. Their findings show that a firm will produce and export a higher quality product to a place with higher consumer preferences when the relative cost of shipping is higher than the unit production costs. They also show that better quality goods are more likely to be sold to high-income destinations. When they decompose the aggregate weighted-average export quality into the intensive and extensive margins, they find that the intensive margin plays a major role in Indonesia's exports, while the extensive margin plays a major role in China's exports. Cui and $\mathrm{Yu}$ (2018) studied the effect of the exchange rate on the domestic value-added ratios of processing exports via two channels: substitution and markup. First, home currency depreciation leads to an increase in domestic value-added ratios by affecting each firm's imported and domestic intermediate inputs (the substitution channel). Second, home currency depreciation improves exporters' profitability and results in higher domestic value-added ratios of processing firms (the markup channel), as exports become more competitive with depreciation. Using Chinese firm-level production data and product-level trade transaction data, they find that processing firms' domestic value-added ratios increase significantly through the two channels in response to firm-level nominal effective exchange rate depreciation. The markup channel contributes almost $39 \%$ of the variation in domestic value-added ratios in response to changes in the exchange rate. 
The third solution is to increase outward foreign direct investment (FDI). Since 2010, the sharp increase in outward FDI from developing countries has been phenomenal, and this is especially true for China. The UNCTAD World Investment Report (UNCTAD, 2015) shows that outward FDI flows from developing economies have already accounted for more than 33\% of overall FDI flows, up from $13 \%$ in 2007. Furthermore, despite the fact that global FDI flows plummeted by $16 \%$ in 2014, multinational corporations (MNCs) from developing economies invested almost $\$ 468$ billion abroad in 2014 , an increase of $23 \%$ over the previous year. As the largest developing country in the world, China has seen an astonishing increase in its outward FDI flows. In 2015, China's outward FDI reached the level of $9.9 \%$ of the world's total FDI flows, making China the second largest home country of FDI outflows globally. In addition, manufacturing outward FDI from China is becoming more important in China's total outward FDI flows, having increased from $9.9 \%$ in 2012 to $18.3 \%$ in 2016.

Chen, Tian, and Yu (2019) examine how domestic distortions affect firms' production strategies abroad by documenting two puzzling findings using Chinese firm-level data from manufacturing firms. First, private MNCs are less productive than state-owned MNCs, but more productive than state-owned enterprises overall. Second, there are disproportionately fewer state-owned MNCs than private MNCs. They also built a model to rationalise these findings by showing that domestic discrimination against private firms incentivises them to produce abroad. The model shows that selection reversal is more pronounced in industries with more severe discrimination against private firms, a theory that receives empirical support. Liu et al. (2017) use unique data on Chinese manufacturing firms over the sample period 2002-08. They find that MNCs are generally more productive after they conduct outward FDI, but this productivity effect varies depending on the parent firm and investment strategy heterogeneity. Their results suggest that MNCs without state ownership but with stronger absorptive capability gain higher and more sustainable productivity effects, and such gains are higher for MNCs investing in countries in the Organisation for Economic Co-operation and Development than elsewhere.

\section{All-around opening up and trade globalisation}

Since the 2008 global financial crisis, there has been a new wave of trade protectionism headed by the US, casting a shadow on the world economy. The current situation arises from the stagnation of the Doha negotiations, the failure of the Transatlantic Trade and Investment Partnership, negotiations among Western countries, the Brexit negotiations, the Trump regime's abolition of the Trans-Pacific Partnership, renegotiation of the North American Free Trade Agreement, and the recent trade war between the US and China, which has resulted in a tremendous shock to world markets. Widespread protectionism could lower global output, making worldwide economic recovery difficult.

One the one hand, Trump's trade war will have a huge impact on the world economy. Guo et al. (2018) used Eaton and Kortum's 2002 multi-sector, 
multi-country general equilibrium model with inter-sectional linkages to forecast how exports, imports, output, and real wages would change if Trump's threat of $45 \%$ tariffs is carried out. To consider plausible scenarios, they evaluate the case of unilateral action on the part of the US, as well as a scenario where China retaliates by imposing an equally high $45 \%$ tariff on its imports from the US. In all of the scenarios, the calibration exercise suggests that a trade war triggered by high US import tariffs will lead to a collapse in US-China bilateral trade. In all of the scenarios, the US will experience large social welfare losses, while China may lose or gain slightly depending on the effect of the trade war on the US-China trade balance. Globally, some small open economies may experience small benefits, while other countries may suffer collateral damage.

On the other hand, China has implemented multiple methods to minimise the impact of Trump's trade war and to continue to open up to the outside world. The first of these is the construction of free trade ports. By definition, a free trade port is a port area within the territory of a country or region that is not subject to the usual customs control, with free access to overseas goods and funds. The main feature of a free trade port is that it is outside the control of the customs authority of a country. It has the features of a port and a free trade zone, with many traderelated functions, including product processing, logistics, and warehousing.

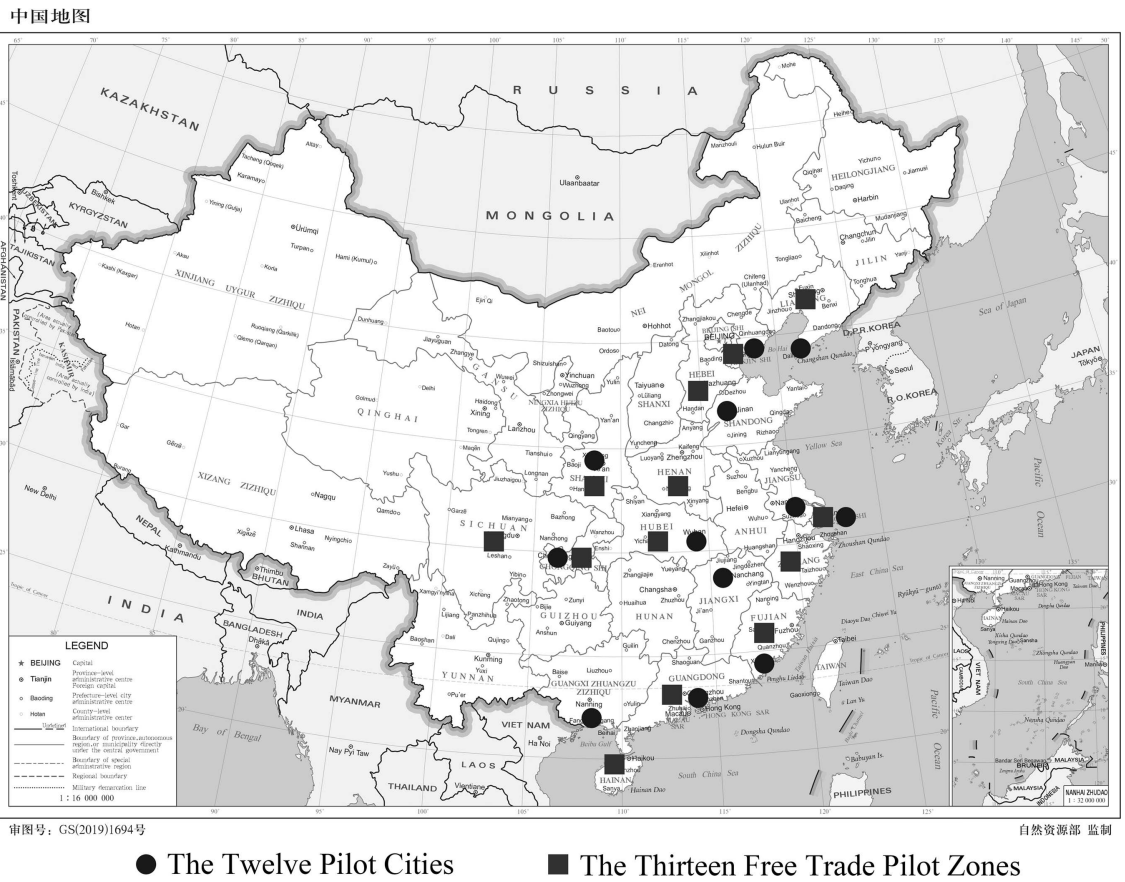

Figure 3.3 Map of the Free Trade Pilot Zones and Pilot Cities.

Source: authors. 
Geographically, a free trade port is part of the territory of a country, but from the perspective of administrative supervision, it is outside the customs jurisdiction of the country. As shown in Figure 3.3, there are 13 free trade pilot zones and twelve pilot cities in China. Tian et al. (2018) suggested three areas to promote the development of free trade ports. First, it is necessary to improve convenience for businesses engaging in trade in the ports. Second, the ports must take steps to improve the fluidity of personnel as well as their ability to attract talent. Finally, the process of improving the ports' financial systems presents an opportunity to deepen financial reform and improve market openness. Moreover, the government should establish a financial leasing system, so that it can provide sufficient capital support for all businesses in ports and encourage more international companies to establish headquarters in the free trade ports.

The second method is the One Belt, One Road initiative (BRI). The BRI, which was initiated by the Chinese government in 2013, is devoted to improving regional cooperation and connectivity on a transcontinental scale. The initiative aims to strengthen infrastructure, trade, and investment links between China and the other BRI countries. Currently, 64 countries are actively involved in the BRI. These include 10 Association of Southeast Asian Nations countries, 18 countries in Western Asia, 8 in South Asia, 5 in Central Asia, 7 in the Commonwealth of Independent States, and 16 in Central and Eastern Europe. Yu (2018a) found

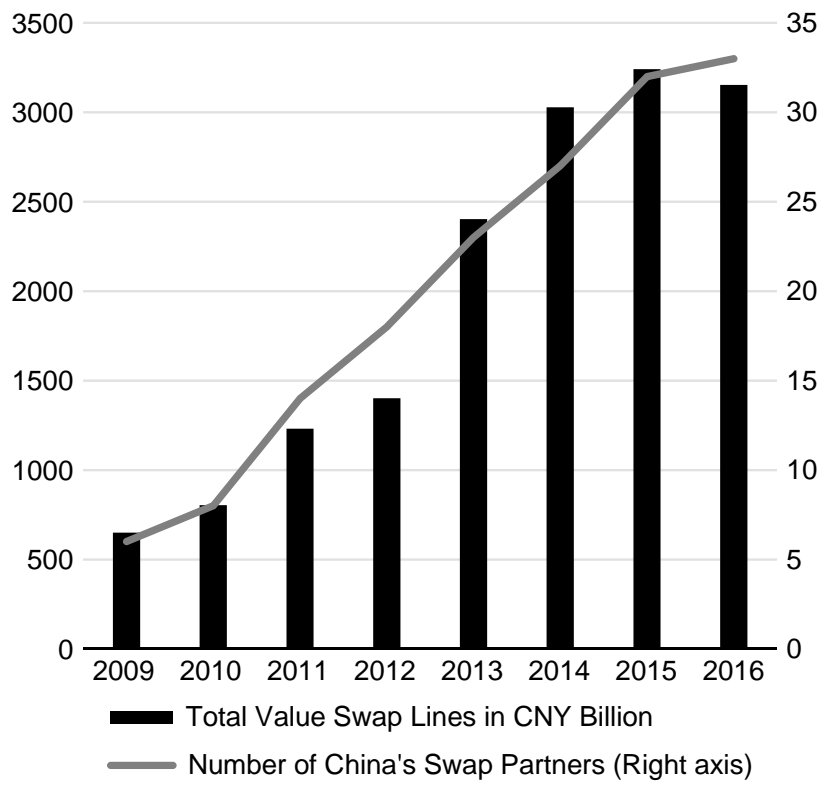

Figure 3.4 China's Bilateral Swap Values and Numbers.

Source: People's Bank of China.

Note: Data of swaps are from the People's Bank of China (2016). This graph does not include swaps under the Chiang Mai Initiative. 


\section{Miaojie Yu and Huibuang Zhu}

that if China chooses to import more intermediate goods from the European Union and Association of Southeast Asian Nations countries, or countries alongside the BRI instead, the price of the intermediate goods would be more competitive, and the Chinese people can also access cheaper finished goods.

The third method is the internationalisation of the renminbi. Since around 2005 , the Government of China has pursued a variety of initiatives designed to encourage wider use of the renminbi. As shown in Figure 3.4, these efforts sped up after the global financial crisis in 2008 and have made great progress since 2009. This progress peaked in 2015 and has slowed in some aspects since 2016. The progress of renminbi internationalisation can be categorised into four fields: renminbi trade settlement, renminbi-denominated investment, renminbi bond issuance, and renminbi currency swaps and direct trading (Eichengreen and Kawai, 2014). Zhang et al. (2018) found a significant positive effect of swap agreements on trade. In their benchmark model, the negotiations of the swap agreement would improve $30.4 \%$ of bilateral trade values between China and its partners. For BRI countries, the effect is even stronger. This effect is both statistically and economically significant. They believe that renminbi swap agreements support economic integration between China and BRI countries by facilitating bilateral trade.

The fourth method is the construction of the Pearl River Greater Bay Area (GBA). If the BRI and Regional Comprehensive Economic Partnership constructions are treated as the key content of the new pattern of all-around opening up, the Guangdong-Hong Kong-Macau GBA indeed is an important domestic carrier of the BRI. Thus, the construction of the Guangdong-Hong Kong-Macau GBA is the most urgent task of China's opening up. Yu (2018b) suggests that the development of the GBA should focus on the following perspectives. First, it is essential for the GBA to focus on manufacturing industries rather than services industries only. Second, the construction of the GBA should focus on innovation. The third objective is to achieve institutional innovation. Fourth, the GBA should pay more attention to its ecological environment.

\section{Note}

1 According to the Chinese statistical yearbook (2008), the dependent rate of China in 2007 was only 0.4 . This number was not only lower than the average dependent rate in east Asia, but also one of the lowest dependent rates all over the world (Yao and $\mathrm{Yu}, 2009)$.

\section{References}

Amiti, M. and J. Konings (2007), 'Trade Liberalization, Intermediate Inputs, and Productivity: Evidence from Indonesia', American Economic Review, 97(5), pp.1611-1638.

Chen, B., M. Yu, and Z. Yu (2017), 'Measured Skill Premia and Trade Liberalization: Evidence from Chinese Firms', Journal of International Economics, 109, pp.31-42. 
Chen, C., W. Tian, and M. Yu (2019), 'Outward FDI and Domestic Input Distortions: Evidence from Chinese Firms', The Economic Journal, 129(624), pp.3025-3057.

Chor, D. and K. Manova (2012), 'Off the Cliff and Back: Credit Conditions and International Trade During the Global Financial Crisis', Journal of International Economics, 87(2012), pp.117-133.

Cui, X. and M. Yu (2018), 'Exchange Rate and Domestic Value Added in Processing Exports: Evidence from Chinese Firms', China Center for Economic Research Working Paper, 2018.

Dai, M. and M. Yu (2013), 'Firm R\&D, Absorptive Capacity, and Learning by Exporting: Firm-Level Evidence from China', The World Economy, 2013, pp.1131-1145.

Dai, M., M. Maitra, and M. Yu (2016), 'Unexceptional Exporter Performance in China? Role of Processing Trade', Journal of Development Economics, 2016, 121, pp.177-189.

Dai, M., M. Yu, and C. Zhao (2018), 'Export Tightening, Competition and Firm Innovation: Evidence from the Renminbi Appreciation', Review of Development Economics, 22(1), pp.263-286.

Eichengreen, B. and D. Leblang (2008), 'Democracy and Globalization', Economics and Politics, 20(3), pp.289-334.

Eichengreen, B. and M. Kawai (2014), 'Issues for Renminbi Internationalization: An Overview', Asian Development Bank Institute Working Paper Series, No. 454. https:// papers.ssrn.com/sol3/papers.cfm?abstract_id=2382420 (accessed 4 Sept. 2019).

Feenstra, R., Z. Li, and M. Yu (2014), 'Exports and Credit Constraints Under Incomplete Information: Theory and Application to China', Review of Economics and Statistics, 96(4), pp.729-744.

Feng, L., Z. Li, and D.L. Swenson (2017), 'Trade Policy Uncertainty and Exports: Evidence from China's WTO Accession', Journal of International Economics, 106, pp.20-36.

Giavazzi, F. and G. Tabellini (2005), 'Economic and Political Liberalization', Journal of Monetary Economics, 52, pp.1297-1340.

Goldberg, P., A. Khandelwal, N. Pavcnik, and P. Topalova (2010), 'Imported Intermediate Inputs and Domestic Product Growth: Evidence from India', Quarterly Journal of Economics, 125(4), pp.1727-1767.

Guo, M., L. Lu, L. Sheng, and M. Yu (2018), 'The Day After Tomorrow: Evaluating the Burden of Trump's Trade War', Asian Economic Papers, 17(1), pp.101-120.

Ing, L.Y., M. Yu, and R. Zhang (2018), 'The Evolution of Export Quality: China and Indonesia', in L.Y. Ing and M. Yu (eds.) World Trade Evolution. Abingdon; New York, NY: Routledge, pp.261-302.

Ing, L.Y., M. Li, and M. Yu (2019), 'Non-Tariff Measure in China', Working paper.

Khandelwal, A.K., P.K. Schott, and S.J. Wei (2013), 'Trade Liberalization and Embedded Institutional Reform: Evidence from Chinese Exporters', American Economic Review, 103(6), pp.2169-2195.

Khandelwal, A. (2010), 'The Long and Short Quality Ladders', Review of Economic Studies, 77, pp.1450-1476.

Loren, B., J. Van Biesebroeck, L. Wang, and Y. Zhang (2017), 'WTO Accession and Performance of Chinese Manufacturing Firms', American Economic Review, 107(9), pp.2784-2820. 


\section{Miaojie Yu and Huibuang Zhu}

Lim, K., D. Trefler, and M. Yu (2019), 'Trade and Innovation: The Role of Scale and Competition', University of Toronto Working Paper.

Lin, J.Y. and M. Yu (2015), 'Industrial Structural Upgrading and Poverty Reduction in China', in A. Szirmai (ed.) Structural Change and Industrial Development in the BRICS. Oxford, UK: Oxford University Press, pp.93-118.

Liu, X., L. Li, M. Yu, and D. Yuan (2017), 'Does Outward FDI Generate Higher Productivity for Emerging Economy MNEs? Micro-Level Evidence from Chinese Manufacturing Firms', International Business Review, 2017(26), pp.839-854.

Ma, Y., H. Tang, and Y. Zhang (2014), 'Factor Intensity, Product Switching, and Productivity: Evidence from Chinese Exporters', Journal of International Economics, 92(2), pp.349-362.

Manova, K., S.J. Wei, and Z. Zhang (2015), 'Firm Exports and Multinational Activity Under Credit Constraints', Review of Economics and Statistics, 97(3), pp.574-588.

Melitz, M.J. (2003), 'The Impact of Trade on Intra-Industry Reallocations and Aggregate Industry Productivity', Econometrica, 71(6), pp.1695-1725.

Mincer, J. (1974), 'Schooling, Experience, and Earnings', Human Behavior and Social Institutions, 2.

Olley, S. and A. Pakes (1996), 'The Dynamics of Productivity in the Telecommunications Equipment Industry', Econometrica, 64(6), pp.1263-1297.

Rodriguez-Lopez, A. and M. Yu (2017), 'All-Around Trade Liberation and Firm Employment: Theory and Evidence from China', University of California, Irvine Working Paper.

Tian, W., I.Y. Yao, M. Yu, and Y. Zhou (2013), 'Structure of Population and International Trade', Jingjïyanjiu, 2013(11), pp.87-99.

Tian, W. and M. Yu (2015), 'Processing Trade, Export Intensity, and Input Trade Liberalization: Evidence from Chinese Firms', Journal of Asia-Pacific Economy, 20(3), pp.444-464.

Tian, W. and M. Yu (2017), 'Firm R\&D, Processing Trade and Input Trade Liberalisation: Evidence from Chinese Firms', The World Economy, 40(2), pp.297-313.

Tian, W., Z. Xu, M. Yu, and H. Zhu (2018), 'China's Free Trade Ports: Effective Actions Against the Threat of De-Globalization', China and the World Economy, 26(4), pp.62-81.

Topalova, P. and A. Khandelwal (2011), 'Trade Liberalization and Firm Productivity: The Case of India', Review of Economics and Statistics, 93(3), pp.995-1009.

UNCTAD. (2015). World Investment Report 2015. https://unctad.org/webflyer/ world-investment-report-2015.

United Nations Conference on Trade and Development (2013), Classification of Non-Tariff Measures, February 2012 Version. Geneva: United Nations Conference on Trade and Development.

Wong, K.-F. and M. Yu (2015), 'Democracy and the GATT/WTO Accession Duration', Review of Development Economics, 19(4), pp.843-859.

Yao, Y. and M. Yu (2009), 'Labor Force, Population and Chinese Export-Oriented Growth Pattern', Jinrongyanjiu, 2009(9), pp.1-13.

Yu, M. (2010a), 'Trade, Democracy, and the Gravity Equation', Journal of Development Economics, 91(2), pp.289-300. 
Yu, M. (2010b), 'Trade Liberalization and the Productivity of Manufacturing Firms', Jingjiyanjiu, 2010(12), pp.97-110.

Yu, M., G. Ye, and B. Qu (2013), 'Trade Liberalization, Product Complexity, and Productivity Improvement: Evidence from Chinese Firms', The World Economy, 36(7), pp.913-934.

Yu, M. and L. Jin (2014), 'Import, Firm Productivity, and Product Complexity', Japanese Economic Review, 65(2), pp.178-192 .

Yu, M. (2015), 'Processing Trade, Tariff Reductions, and Firm Productivity: Evidence from Chinese Firms', Economic Journal, 125(585), pp.943-988.

$\mathrm{Yu}, \mathrm{M}$. and L. Jin (2015), 'Imports, Heterogeneous Industry and Improvement of Firm Productivity', Jinjiyanjiu, 2015(8), pp.85-97.

Yu, M. and D. Yuan (2016), 'Trade Liberalization, Processing Trade and Markup', Guanlishijie, 2016(9), pp.33-43.

$\mathrm{Yu}$, M. and L. Li (2016), 'Trade Liberalization and Quality Upgrading of Intermediate Inputs: Evidence from Chinese Customs Data', China Economic Quarterly, 2016(3), pp.1011-1029.

Yu, M. and K. Zhi (2016), 'Import Liberalization and Firm Profitability', Jingjiyanjiu, 2016(8), pp.57-71.

Yu, M, and R. Zhang (2017). 'Estimating China's manufacturing export quality: pitfalls and remedy', China Economic Quarterly, 1, pp.463-484.

Yu, M. (2018a), 'Expanding Opening Up: China's Olive Branch to Globalization', China Economic Transition, 1(3), pp.66-75.

Yu, M. (2018b), 'China's International Trade Development and Opening-up Policy Design', China Economic Journal, 11(3), pp.301-318.

Zhang, F., M. Yu, J. Yu, and Y. Jin (2018), 'The Effect of RMB Internationalization on Belt and Road Initiative', Emerging Markets Finance \& Trade, 53(12), pp.2845-2857. 